\title{
Color and antibacterial activity of annatto extracts at various pH of distilled water solvent and extraction temperature
}

\author{
1,*Handayani, I., ${ }^{1}$ Haryanti, P. and ${ }^{2}$ Sulistyo, S.B. \\ ${ }^{1}$ Department of Agricultural Technology, Faculty of Agriculture, Jenderal Soedirman University, \\ Purwokerto, Indonesia \\ ${ }^{2}$ Department of Agricultural Engineering, Faculty of Agriculture, Jenderal Soedirman University, \\ Purwokerto, Indonesia
}

\author{
Article history: \\ Received: 16 December 2020 \\ Received in revised form: 10 \\ February 2021 \\ Accepted: 16 May 2021 \\ Available Online: 28 \\ December 2021 \\ Keywords: \\ Annatto, \\ Extraction, \\ $\mathrm{pH}$, \\ Temperature
}

DOI:

https://doi.org/10.26656/fr.2017.5(6).740

\begin{abstract}
Annato (Bixa orrelana L.) has been renowned as a tropical plant rich in carotenoid pigments such as nonpolar bixin and polar norbixin. This study was aimed to obtain natural colorant and antimicrobials from annatto extracts. The extraction was carried out by maceration for 10 mins using distilled water as the extraction solvent at various $\mathrm{pH}$ and extraction temperatures. The variations of solvent $\mathrm{pH}$ used in this research were 4,7 , and 9 , while that of extraction temperatures were 70,80 , and $90^{\circ} \mathrm{C}$. The potential of annatto extract as an antimicrobial agent was tested by analyzing the extract's ability to inhibit pathogens and its phytochemical compounds. Escherichia coli and Staphylococcus aureus were used as the pathogenic bacteria by using the agar diffusion method. The color of annatto extracts was measured using Munsel Chard to determine the level of hue (color), value (brightness), and chroma (intensity), as well as maximum absorbance. The results showed that all extracts have the potential to inhibit E. coli and $S$ aureus (weak-moderate). The observed annatto extracts had different color intensities as indicated by the hue, value, and chroma and a maximum absorbance at a wavelength of $400 \mathrm{~nm}$.
\end{abstract}

\section{Introduction}

In recent years, public concern about synthetic pigments and preservatives' safety has led to increasing interest in developing natural food colorants and preservatives from plant tissues, especially from some edible sources (He et al., 2015; Ramli et al., 2017). Bixa orellana (annatto) is one of the plants that have high potential as a colorant. Annatto obtained from Bixa orellana fruit is one of the natural pigments used as a natural food colorant. The main pigment of annatto is carotenoid composed of bixin and norbixin (GallardoCabrera and Rojas-Barahona, 2015) as well as $\beta$ carotene, cryptoxanthin, lutein, zeaxanthin, and methyl bixin (Scotter et al., 2000).

Annato pigment has a high tinctorial value and an outer colour range comprising red, orange, and yellow hues (Husa et al., 2018). This range of colours is an additional advantage of the annatto carotenoids over other carotenoids such as carrot and beetroot, which only show their respective colours (Silva et al., 2008). Bixin (nonpolar) is more soluble in vegetable oil; on the other hand, norbixin (polar) is more soluble in an aqueous solution. As a colorant, annatto is used in cheeses, sausages, meat, and candies industries (Silva et al., 2008). The dairy industry is the biggest usage of annatto pigment. Annato extract, apart from being a potential colorant, also has the potential to be a natural antimicrobial (Venugopalan and Giridhar, 2012; Yolmeh et al., 2014).

Carotenoids are susceptible to enzymatic or nonenzymatic oxidation, which depends on the carotenoid structure, oxygen availability, enzymes, metals, prooxidants and antioxidants, high temperature, and light exposure (Mezzomo and Ferreira, 2016). Colour loss of annatto extracts occurs upon prolonged exposure to light, elevated temperature, and in the presence of sulfur dioxide (Satyanarayana et al., 2003). $\mathrm{Gu}$ et al. (2008) evaluated the addition of $\mathrm{HCl}$ to optimize the extraction process. The results proved that the pre-treatment using $\mathrm{HCl}$ was the most effective method for carotenoids extraction.

Three main commercial processes are commonly used to extract the pigment from dried annatto seeds, direct extraction into oil, direct extraction into aqueous 
alkali, or indirect extraction with solvents (Scotter et al., 2000). The major colouring principles produced by direct oil extraction are 9'-cis-bixin, all-trans-bixin, to provide a colour formulation suitable for fat- or oil-based products such as margarine. Annatto extracts are susceptible to oxidative degradation.

Direct aqueous alkali extraction produces alkali metal or ammonium salt solutions of $9^{\prime}$-cisnorbixin plus a small amount of the very poorly soluble all-trans isomer. Alternatively, the free acid form of norbixin can be precipitated with dilute acid, filtered, washed, and dried to produce a solid formulation (Scotter et al., 2000). Annatto extraction using distilled water is profitable since distilled water is an edible solvent, easy to obtain, and cheap. In this study, annatto extraction was carried out using acidic and alkaline distilled water at several different extraction temperatures. According to Satyanarayana et al. (2003), yellowness of extract increased, and redness decreased with an increase in temperature. However, the colour characteristics and antibacterial activity of distilled-water based extract at acidic and alkaline $\mathrm{pH}$ and various extraction temperatures have not been widely published.

\section{Materials and methods}

\subsection{Annato extraction}

Annato extraction was carried out in accordance with studies conducted by (Rosamah et al., 2009) and Abayomi et al. (2014). A total of $25 \mathrm{~g}$ of annatto seeds was added to $90 \mathrm{~mL}$ of distilled water as the solvent. Maceration was performed through a magnetic stirrer at various heating temperatures of 70,80 , and $90^{\circ} \mathrm{C}$ for 30 mins. Two acidity levels of distilled water were applied, $\mathrm{pH} 4$ and 9. Distilled water with $\mathrm{pH} 4$ was adjusted by adding citric acid, while that with $\mathrm{pH} 9$ was adjusted using $\mathrm{Ca}(\mathrm{OH})_{2}$. After extraction, the mixture was filtered to separate the extract from the annatto seeds.

\subsection{Phytochemical analysis}

Preliminary screening of secondary metabolites such as alkaloids, flavonoids, saponins, coumarins, anthraquinones, terpenoids, steroids and sterols were carried out according to the common phytochemical methods described by Harborne (1973).

\subsection{Antimicrobial activity}

The antibacterial activity of annatto extracts was assessed against Escherichia coli FNCC -19 and Staphylococcus aureus FNCC-15. The stock bacteria were grown on nutrient agar (Merk) then activated using nutrient broth (Merk) at $37^{\circ} \mathrm{C}$ for $24 \mathrm{hrs}$ and then kept at $4^{\circ} \mathrm{C}$ before further experiments (Bakht et al., 2011). Agar well diffusion method was followed to determine the antimicrobial activity. Wells (10 $\mathrm{mm}$ diameter) were made in each of these plates using a sterile cork borer. Activating cultures bacteria of the pathogen were cultured in nutrient broth by poured plates. About 100 $\mu \mathrm{L}$ of annatto extracts were added using a sterile syringe into the wells and diffused at room temperature for $2 \mathrm{hrs}$. Control experiments comprising inoculums without plant extract were set up. The plates were incubated at $37^{\circ} \mathrm{C}$ for 5 days. The diameter of the inhibition zone $(\mathrm{mm})$ was measured.

\subsection{Colour extracts measurement}

Colour of extracts measured utilizing Munsell Colour Chart (Ahmed et al., 2002) to determine hue, value, and chroma. The maximum absorbance of the extract was determined using spectrophotometry. Hue states the name of the colour, and the value represents the level of brightness or colour brilliance, while chroma declares colour intensity, strength, or purity. The maximum absorbance of the extract was determined using spectrophotometry, according to Abayomi et al. (2014), with some modification.

\section{Results and discussion}

\subsection{Phytochemical compounds}

The phytochemical diversity of antimicrobial compounds includes terpenoids, saponins, phenolics and phenylpropanoids, pterocarpans, stilbenes, alkaloids glucosinolates, hydrogen cyanide, indole, and also elemental sulfur, the sole inorganic compound (Shakeri et al., 2012). In this study, the phytochemical analysis of the annatto extract (Table 1) showed the presence of different groups of secondary metabolites such as alkaloid, phenol, tannin, and saponin

Annatto extract in distilled water solvent showed the presence of alkaloid, phenol, tannin, and saponin, but not flavonoid. The alkaloid content, tannin, and saponin in the extract were moderate to appreciable, while phenol was in trace amount, but flavonoid was not detected. The lower phenol content in extracts might be explained by the low solubility of phenols in distilled water. The extract had the highest level of alkaloid and tannin compared to other compounds. The relationships between tannins contents and extraction solvents could be related to the polymerization degree for the tannins extracted by different solvents (Naima et al., 2015). The interactive abilities of solvent and flavonoids or tannins compounds are probably related to chemical compositions and structures. The tannins' solubility is correlated to the degree of polymerization due to the increase in the number of hydroxyl groups - $\mathrm{OH}$ (Felhi et al., 2017). In general, phenolic compounds' solubility 
Table 1. Phytochemical screening in seed extract of annatto

\begin{tabular}{ccccccc}
\hline \multicolumn{2}{c}{ Treatment } & \multicolumn{5}{c}{ Phytochemical } \\
\hline $\mathrm{pH}$ of solvent & Temperature $\left({ }^{\circ} \mathrm{C}\right)$ & Alcoloid & Flavonoid & Phenol & Tannin & Saponin \\
\hline 4 & 70 & ++ & - & + & + & + \\
& 80 & +++ & - & + & ++ & ++ \\
& 90 & +++ & - & + & +++ & +++ \\
\hline 9 & 70 & ++ & - & + & ++ & ++ \\
& 80 & +++ & - & + & ++ & ++ \\
& 90 & ++ & - & + & +++ & ++ \\
\hline
\end{tabular}

+++ Appreciable amount, ++ Moderate amount, +Trace amount, -Absent

depends not only on the type of solvent used but also on the degree of polymerization and interaction of phenolics with other phytochemicals, vitamins, and minerals (Naczk and Shahidi, 2004).

The solvent's pH did not affect phytochemical levels, but increasing in temperature caused an increase in phytochemical levels. It was suspected that the phytochemical compounds in annatto have similar solubility levels in distilled water at acidic and alkaline $\mathrm{pH}$. The higher the extraction temperature caused more water in the extract to evaporate, thus, the extract's phytochemical compounds concentration increased.

Phytochemical constituents such as alkaloids, flavonoids, tannins, phenols, saponins, and several other aromatic compounds are secondary metabolites of plants that serve as antimicrobial. The recovery of phytochemicals from the plant could be influenced by the dielectric constant, chemical structure of organic solvents, and chemical properties of plant phytochemicals.

\subsection{Antibacterial activity of extracts}

Evaluation of the antibacterial activity of annatto extracts was determined by measuring the inhibition zone against $E$. coli and S. aureus (Table 2)

Table 2. Antimicrobial activity of annatto extract

\begin{tabular}{cccc}
\hline \multicolumn{2}{c}{ Treatment } & \multicolumn{2}{c}{ Inhibition zone (mm) } \\
\hline pH extraction & $\begin{array}{c}\text { Temperature } \\
\left({ }^{\circ} C\right)\end{array}$ & E. coli & S. aureus \\
\hline 4 & 70 & $6.67 \pm 1.11^{\mathrm{a}}$ & $6.33 \pm 2.08^{\mathrm{bc}}$ \\
& 80 & $7.00 \pm 1.00^{\mathrm{a}}$ & $9.33 \pm 0.57^{\mathrm{a}}$ \\
& 90 & $7.00 \pm 1.36^{\mathrm{a}}$ & $7.33 \pm 1.52^{\mathrm{ab}}$ \\
\hline 9 & 70 & $3.33 \pm 2.31^{\mathrm{ab}}$ & $5.67 \pm 1.15^{\mathrm{bc}}$ \\
& 80 & $4.67 \pm 0.60^{\mathrm{b}}$ & $4.33 \pm 0.57^{\mathrm{c}}$ \\
& 90 & $7.00 \pm 1.70^{\mathrm{a}}$ & $4.33 \pm 1.15^{\mathrm{c}}$ \\
\hline
\end{tabular}

Values with different superscript within the same column are significantly different $(\mathrm{p}<0.05)$.

As seen in Table 2, all the extracts were potent antimicrobials against $E$. coli and $S$ aureus. Annato extract produced from $\mathrm{pH} 4$ at $80^{\circ} \mathrm{C}$ showed the highest degree of inhibition against $S$ aureus with a diameter of
$0.93 \pm 0.06 \mathrm{~mm}$, while the lowest degree was produced from $\mathrm{pH} 9$ at $70^{\circ} \mathrm{C}$. Based on the inhibition zone's diameter, the annatto extract produced at $\mathrm{pH} 4 \mathrm{had}$ moderate inhibition at $\mathrm{pH}$ 9. According to Tari and Handayani (2015), the antibacterial activity of a bacterium is determined based on the diameter of the bacterial inhibition zone against indicator bacteria, which are generally pathogenic bacteria with a range of $>20$ $\mathrm{mm}=$ very strong, $10-20 \mathrm{~mm}=$ strong, $5-10 \mathrm{~mm}=$ moderate and $<5 \mathrm{~mm}=$ weak. The antibacterial activity is thought to be produced by phenolic compounds.

In this study, $S$. aureus was more susceptible to the tested extracts than E. coli. Indeed, the majority of the compound's extracts assayed for their antibacterial properties showed a more pronounced effect against the Gram-positive bacteria. The resistance of Gram-negative bacteria has been ascribed to their hydrophilic outer membrane, which can block the penetration of antibacterial compounds into the target cell membrane. The wall of Escherichia coli is very rich in lipopolysaccharide (LPS) that prevents antibacterial molecules such as phenol. The resistance of Staphylococcus aureus to some plant extracts can be explained by the heterogeneous wall structure of the bacteria: the presence of the exopolysaccharide containing an outer layer (glycocalyx), the presence of certain components such as the teichoic acid, and links between the various components highly cross-linked polymer give the walls an unknown tertiary structure (Bouyahya, 2016).

Phenolic compounds are one of the most diverse groups of secondary metabolites found in edible plants. It was reported that an antimicrobial action of phenolic compounds was related to the inactivation of cellular enzymes, which depended on the rate of penetration of the substance into the cell or caused by membrane permeability changes. Increased membrane permeability is a major factor in the mechanism of antimicrobial action, where compounds may disrupt membranes and cause a loss of cellular integrity and eventual cell death.

Tannins bind to proline-rich proteins and interfere with protein synthesis. Flavonoids are hydroxylated phenolic substances known to be synthesized by plants in 
response to microbial infection. It should not be surprising that they have been found in vitro to be effective antimicrobial substances against a wide array of microorganisms. Their activity is probably due to their ability to complex with extracellular and soluble proteins and to complex with bacterial cell walls. The antimicrobial property of saponin is due to its ability to cause leakage of proteins and certain enzymes from the cell (Kumaravel and Alagusundaram, 2014). Kumaravel and Alagusundaram (2014) reported that the hydroxyl ($\mathrm{OH})$ group in phenolic compounds might cause bacterial inhibition and described the importance of double bonds (number and position) concerning antimicrobial effectiveness.

Phenols interact with proteins form phenol protein complexes. The bond between protein and phenol is a weak bond and breaks down immediately. Free phenol will penetrate bacterial cells, causing precipitation and protein denaturation. Phenol can cause protein coagulation so that the cell membrane undergoes lysis. The occurrence of lysis in the cell membrane results in leakage in the cell so that the essential metabolites needed by microbes leave the cell. Phenol in the cell will damage the cell work system, damage the cytoplasmic membrane, which results in inhibition of cell growth or cell death, denatures proteins, nucleic acids, inhibits nucleic acid and protein synthesis (Ngazizah et al., 2017)

Steroids have been reported to have antibacterial properties, the correlation between membrane lipids and sensitivity for steroidal compounds indicates the mechanism in which steroids specifically associate with membrane lipid and exert their action by causing leakages from liposomes

\subsection{Colour extract measurement determined using Munsell colour chard}

Hue, value, and chroma were determined using the Munsell colour chart (Ruck and Brown, 2015). The results of the colour readings of annatto extract using the Munsell chart showed that the use of different $\mathrm{pH}$ of the solvent and temperature extraction produces different extract hue.

\subsubsection{Huе}

The hue of extract determination using the Munsell Chart is shown in Table 3.

Table 3 indicates that the hue of all off extracts was YR, which showed yellowish red (orange). Extraction using $\mathrm{pH} 4$ of distilled water at $80^{\circ} \mathrm{C}$ resulted in the highest hue of annatto extract. Acidic solutions at high temperatures are thought to be more capable of extracting pigment compounds to produce a higher hue
(Saputri et al., 2017). High temperature, acidic $\mathrm{pH}$ solvent, and stirring using a magnetic stirrer are thought to enhancement abrasion of the annatto seed exocarp, thereby increasing colour intensity. The highest colour of the annatto extract was 7.5 YR of hue produced by extraction at $\mathrm{pH} 4$ and $80^{\circ} \mathrm{C}$. This value was not different from that produced by extraction at $\mathrm{pH} 4$ and $90^{\circ} \mathrm{C}$.

Increasing the extraction temperature from $70^{\circ} \mathrm{C}$ to $80^{\circ} \mathrm{C}$ at $\mathrm{pH} 4$ increased the colour intensity of the extract indicated by the hue's enhancement. The increase in hue level indicates a higher orange (yellowish-red) colour. An increase in extraction temperature causes a change in stereoisomers from cis-bixin to trans-bixin, which is more stable (Satyanarayana et al., 2003). Cis bixin is most soluble in organic polar solvents, giving it an orange colour. High temperature can change cis bixin to trans bixin, which is more stable and gives a red colour. Rosamah et al. (2009) also reported that Annatto pigment is more stable at acidic $\mathrm{pH}$. According to Scotter (2009), bixin and norbixin are relatively polar carotenoids.

Table 3. The hue of extract based on measurement using Munsell Chart

\begin{tabular}{ccc}
\hline \multicolumn{2}{c}{ Treatment } & Colour criteria \\
\hline $\mathrm{pH}$ extraction & Temperature $\left({ }^{\circ} \mathrm{C}\right)$ & Hue \\
\hline 4 & 70 & $2.5 \mathrm{YR}^{\mathrm{c}}$ \\
& 80 & $7.5 \mathrm{YR}^{\mathrm{a}}$ \\
& 90 & $7.5 \mathrm{YR}^{\mathrm{a}}$ \\
\hline 9 & 70 & $5 \mathrm{YR}^{\mathrm{b}}$ \\
& 80 & $5 \mathrm{YR}^{\mathrm{b}}$ \\
& 90 & $5 \mathrm{YR}^{\mathrm{b}}$ \\
\hline
\end{tabular}

Hue in the same column for each test, followed by a different superscript are significantly different $(\mathrm{p}<0.05)$. YR: YellowRed colour

The colour component of the extract in distilled water was norbixin in the form of cis norbixin or transnorbixin (Satyanarayana et al., 2003). It is suspected that the form of norbixin in the extract is more dominant so that the resulting colour is more stable. According to Mota et al. (2016), bixin produces a red colour while norbixin produces an orange colour.

Ruck and Brown (2015) reported that hue is divided into five principal sections, based on the colours red (R), yellow $(Y)$, green $(\mathrm{G})$, blue $(\mathrm{B})$, and purple $(\mathrm{P})$. These five hues have intermediate classifications as well, YR lies between red and yellow, resulting in 10 distinct hue designations, each with four sub-divisions. Hue is the dominant colour spectrum according to its wavelength (Priandana et al., 2016). 


\subsubsection{Value}

Value is the lightness of the colour according to the amount of light reflected (Astiningrum et al., 2018). The value of extract annatto determination using the Munsell Chart is shown in Table 4.

Table 4. Value of extract based on measurement using Munsel Chart

\begin{tabular}{ccc}
\hline \multicolumn{2}{c}{ Treatment } & Colour criteria \\
\hline $\mathrm{pH}$ extraction & Temperature $\left({ }^{\mathrm{o}} \mathrm{C}\right)$ & Value \\
\hline 4 & 70 & $5.5^{\mathrm{b}}$ \\
& 80 & $6^{\mathrm{a}}$ \\
& 90 & $6^{\mathrm{a}}$ \\
\hline 9 & 70 & $4^{\mathrm{e}}$ \\
& 80 & $5^{\mathrm{c}}$ \\
& 90 & $4.5^{\mathrm{d}}$ \\
\hline
\end{tabular}

Values with different superscript within the same column are significantly different $(\mathrm{p}<0.05)$.

Based on Table 4, extraction using $\mathrm{pH} 4$ distilled water produced higher value extracts, which indicates a lighter colour. The higher the value, the more light is reflected. It was suspected that $\mathrm{pH} 4$ of solvents is better to extract the annatto pigment. The temperature of $80^{\circ} \mathrm{C}$ was more effective for extracting annatto pigments compared to temperatures of $70^{\circ} \mathrm{C}$ and $90^{\circ} \mathrm{C}$. The more pigment produced, the more light is transmitted, resulting in a higher value.

This result is different from Paryanto et al. (2014), who stated that annatto extraction using $0.25 \mathrm{~N} \mathrm{NaOH}$ solvent is more effective at $60^{\circ} \mathrm{C}$, and extraction at $70^{\circ} \mathrm{C}$ produces lower amounts of bixin. Furthermore, Paryanto et al. (2014) stated that annatto extraction at higher temperatures and a long time could cause the bixin compound's degradation. The annatto extraction using distilled water at a temperature of $90^{\circ} \mathrm{C}$ produced the extract with the highest absorbance compared to extraction at lower temperatures (Rosamah et al., (2013).

\subsubsection{Chroma}

Chroma is a dimension related to the bright or gloomy colour. According to Widiantoro (2008), colour intensity is the level of strength/purity of a colour. The higher of chroma, the brighter of colour, the higher the purity of its colour. Chroma of extract determination using Munsell Chart as shown in Table 5.

Table 5 shows that distilled water $\mathrm{pH} 4$ produced the highest chroma, while $\mathrm{pH} 9$ produced the lowest chroma. It was suspected that $\mathrm{pH} 4$ distilled water was better to be used to extract colour, resulting in more pigment. More pigment produced a brighter/stronger colour. On the other hand, distilled water $\mathrm{pH} 9$ is thought to be less able to extract annatto pigment resulting in lower colour intensity (chroma).

Table 5. Chroma of extract based on measurement using Munsel Chart

\begin{tabular}{ccc}
\hline \multicolumn{2}{c}{ Treatment } & Colour criteria \\
\hline pH extraction & Temperature $\left({ }^{\circ} \mathrm{C}\right)$ & Chroma \\
\hline 4 & 70 & $7^{\mathrm{d}}$ \\
& 80 & $10^{\mathrm{a}}$ \\
& 90 & $10^{\mathrm{a}}$ \\
\hline 9 & 70 & $8^{\mathrm{c}}$ \\
& 80 & $10^{\mathrm{a}}$ \\
& 90 & $9^{\mathrm{b}}$ \\
\hline
\end{tabular}

Values with different superscript within the same column are significantly different $(\mathrm{p}<0.05)$.

\subsection{Maximum absorbance of extracts}

The results of the absorbance of annatto extract at variations of solvent $\mathrm{pH}$ and extraction temperature are shown in Figure 1.

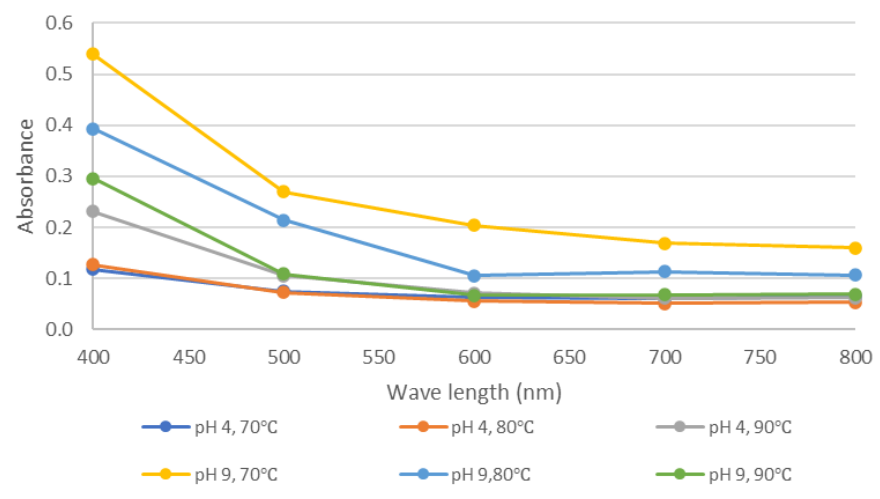

Figure 1. The absorbance of annatto extract at variations in solvent $\mathrm{pH}$ and extraction temperature.

The maximum wavelength of each extraction was at the same wavelength, namely $400 \mathrm{~nm}$ with different absorbance values. Extraction using $\mathrm{pH} 9$ of distilled water at a temperature of $70^{\circ} \mathrm{C}$ produced the highest absorbance of 0.539 . Extraction using distilled water $\mathrm{pH}$ 4 at $70^{\circ} \mathrm{C}$ produced the lowest absorbance of 0.045 (the extract was diluted $200 \times$ ). Judging from the curve measured using a visible spectrophotometer, the shape of the curve is relatively the same. Extraction using $\mathrm{pH} 9$ solvent resulted in a higher absorbance. It is suspected that the $\mathrm{pH} 9$ extract had a compound with a higher conjugation rate, so it was better able to absorb the colour.

\section{Conclusion}

Annatto extraction using distilled water at a temperature of 70 to $90^{\circ} \mathrm{C}$ produces extracts containing phytochemicals alkaloid, phenol, tannins, and saponins, which can be antibacterial against $E$. coli and $S$ aureus 
with low to moderate inhibition power. Annatto extraction using distilled water $\mathrm{pH} 4$ at 80 and $90^{\circ} \mathrm{C}$ results in the highest extract colour, namely $7.5 \mathrm{YR}$ of hue, 6 of value, and 10 of chroma. All extracts have a maximum wavelength at $400 \mathrm{~nm}$, while the absorbance of the extract produced in $\mathrm{pH} 9$ distilled water is higher than that produced in $\mathrm{pH} 4$

\section{Conflict of interest}

The authors declare no conflicts of interest.

\section{Acknowledgments}

This research was fully supported by Jenderal Soedirman University, through Riset Peningkatan Kompetensi 2020.

\section{References}

Abayomi, M., Adebayo, A.S., Bennett, D., Porter, R. and Shelly-Campbell, J. (2014). In vitro antioxidant activity of Bixa orellana (Annatto) seed extract. Journal of Applied Pharmaceutical Science, 4(2), 101-106. https://doi.org/10.9734/BJPR/2014/10925

Ahmed, J., Shivhare, U.S. and Kaur, M. (2002). Thermal colour degradation kinetics of mango puree. International Journal of Food Properties, 5(2), 359366. https://doi.org/10.1081/JFP-120005791

Astiningrum, M., Arhandi, P. and Fatmawati, E. (2018). Pengembangan aplikasi munsell soil color detection chartindex menggunakan metode support vector machine. Jurnal Informatika Polinema, 4(2), 131138. [In Bahasa Indonesia]. https://doi.org/10.33795/ jip.v4i2.161

Bakht, J., Ali, H., Khan, M.A., Khan, A., Saeed, M., Shafi, M., Islam, A. and Tayyab, M. (2011). Antimicrobial activities of different solvents extracted samples of Linum usitatissimum by disc diffusion method. African Journal of Biotechnology, 10(85), 19825-19835. https://doi.org/10.5897/ AJB11.229

Bouyahya, A. (2016). Determination of phenol content and antibacterial activity of five medicinal plants ethanolic extracts from North-West of Morocco. Journal of Plant Pathology and Microbiology, 7(4), 1000342 . https://doi.org/10.4172/21577471.1000342

Felhi, S., Daoud, A., Hajlaoui, H., Mnafgui, K., Gharsallah, N. and Kadri, A. (2017). Solvent extraction effects on phytochemical constituents profiles, antioxidant and antimicrobial activities and functional group analysis of Ecballium elaterium seeds and peels fruits. Food Science and Technology,
$37(3), \quad 483-492$. $457 \times .23516$

Gallardo-Cabrera, C. and Rojas-Barahona, A. (2015). Stability study of an aqueous formulation of the annatto dye. International Food Research Journal, 22(5), 2149-2154.

Gu, Z., Deming, C., Yongbin, H., Zhigang, C. and Feirong, G. (2008). Optimization of carotenoids extraction from Rhodobacter sphaeroides. LWT Food Science and Technology, 41(6), 1082-1088. https://doi.org/10.1016/j.lwt.2007.07.005

Harborne, J.B. (1973). Method of Plant Analysis. In Phytochemical Methods. Dordrecht, the Netherlands: Springer. https://doi.org/10.1007/978-94-009-59217_1

He, X.L., Li, X.L., Lv, Y.P. and He, Q. (2015). Composition and color stability of anthocyaninbased extract. Food Science and Technology, 35(3), 468-473. https://doi.org/10.1590/1678-457X.6687

Husa, N.N., Hamzah, F. and Said, H.M. (2018). Characterization and storage stability study of bixin extracted from Bixa orellana using organic solvent. IOP Conference Series: Materials Science and Engineering, 358(1), $012035 . \quad \mathrm{https}: / /$ doi.org/10.1088/1757-899X/358/1/012035

Kumaravel, S. and Alagusundaram, K. (2014). Antimicrobial activity and phytochemical analysis of selected Indian spices. Journal of Pure and Applied Microbiology, 8(5), 4131-4136.

Mezzomo, N. and Ferreira, S.R.S. (2016). Carotenoids functionality, sources, and processing by supercritical technology: A Review. Journal of Chemistry, 2016, 3164312. https:// doi.org/10.1155/2016/3164312

Naczk, M. and Shahidi, F. (2004). Extraction and analysis of phenolics in food. Journal of Chromatography A, 1054(1-2), 95-111. https:// doi.org/10.1016/S0021-9673(04)01409-8

Naima, R., Oumam, M., Hannache, H., Sesbou, A., Charrier, B., Pizzi, A. and Charrier-El Bouhtoury, F. (2015). Comparison of the impact of different extraction methods on polyphenols yields and tannins extracted from Moroccan acacia Mollissima Barks. Industrial Crops and Products, 70, 245-252. https://doi.org/10.1016/j.indcrop.2015.03.016

Ngazizah, F. N., Ekowati, N. and Septiana, A.T. (2017). Potensi daun trembilungan (Begonia hirtella Link) sebagai antibakteri dan antifungi. Biosfera, 33(3), 126. [In Bahasa Indonesia]. https:// doi.org/10.20884/1.mib.2016.33.3.309

Paryanto, Hermiyanto, D.S. and Sanjaya. (2014). Pembuatan zat warna alami dari biji kesumba dalam 
bentuk konsentrat tinggi untuk pewarna makanan. Ekuilibrium, 13(2), 55-58. [In Bahasa Indonesia]. https://doi.org/10.20961/ekuilibrium.v13i2.2162

Priandana, K., Ahmad Zulfikar, S. and Sukarman, S. (2016). Mobile munsell soil color chart berbasis android menggunakan histogram ruang citra hvc dengan klasifikasi KNN. Jurnal Ilmu Komputer dan Agri-Informatika, 3(2), 93-101. [In Bahasa Indonesia]. https://doi.org/10.29244/jika.3.2.93-101

Ramli, S., Radu, S., Shaari, K. and Rukayadi, Y. (2017). Antibacterial activity of ethanolic extract of Syzygium polyanthum L. (Salam) leaves against foodborne pathogens and application as food sanitizer. Biomed Research International, 2017, 9024246. https://doi.org/10.1155/2017/9024246

Rosamah, E., Ramadan, R. and Kusuma, I.W. (2009). Stabilitas warna biji tumbuhan annatto (Bixa orellana L.) sebagai bahan pewarna alami, presented at the Seminar Nasional XVI. Masyarakat Peneliti Kayu Indonesia (MAPEKI), p. 209-214. Balikpapan, Kalimantan Timur, Indonesia: Masyarakat Peneliti Kayu Indonesia (MAPEKI) [In Bahasa Indonesia].

Ruck, L. and Brown, C.T. (2015). Quantitative analysis of munsell color data from archeological ceramics. Journal of Archaeological Science: Reports, 3, 549557. https://doi.org/10.1016/j.jasrep.2015.08.014

Saputri, R.A. and Adriana, W.N. (2017). Pengaruh lama pencelupan terhadap warna yang dihasilkan pada bahan sutera menggunakan zat warna alam ekstrak daun puring (Codiaeum vaariegatum) dengan mordan jeruk nipis. E Jurnal Home Economic and Taurism, 14(1), 1-16. [In Bahasa Indonesia].

Satyanarayana, A., Prabhakara Rao, P.G. and Rao, D.G. (2003). Chemistry, processing and toxicology of annatto (Bixa orellana L.). Journal of Food Science and Technology, 40(2), 131-141.

Scotter, M.J., Wilson, L.A., Appleton, G.P. and Castle, L. (2000). Analysis of annatto (Bixa orellana) food coloring formulations. Determination of aromatic hydrocarbon thermal degradation products by gas chromatography. Journal of Agricultural and Food Chemistry, 48(2), 484-488. https://doi.org/10.1021/ jf9901845

Silva, G.F., Gamarra, F.M.C., Oliveira, A.L. and Cabral, F.A. (2008). Extraction of bixin from annatto seeds using supercritical carbon dioxide. Brazilian Journal of Chemical Engineering, 25(2), 419-426. https:// doi.org/10.1590/S0104-66322008000200019

Tari, I.N. and Handayani, C.B. (2015). Evaluation of antidiarrheal potential of indigenous Lactobacillus sp. Jurnal Teknologi Hasil Pertanian, VIII(2), 6370. https://doi.org/10.20961/jthp.v0i0.12890
Venugopalan, A. and Giridhar, P. (2012). Bacterial growth inhibition potential of annatto plant parts. Asian Pacific Journal of Tropical Biomedicine, 2(3), S1879-S1882. https://doi.org/10.1016/S2221-1691 (12)60513-9

Widiantoro, B. (2008). Warna. Retrieved from website: docplayer.info/33152226-Nirmana-i-semester-01warna-hue-value-chroma-pengelompokan-karakterwarna-bayu-widiantoro.html

Yolmeh, M., Najafi, M.B.H., Farhoosh, R. and Salehi, F. (2014). Modeling of antibacterial activity of annatto dye on Escherichia coli in mayonnaise. Food Bioscience, 8, 8-13. https://doi.org/10.1016/ j.fbio.2014.09.001

Shakeri, A., Hazeri, N., Vlizadeh, J., Ghaseni, A. and Zaker Tavallaie, F. (2012). Phytochemical screening, antimicrobial and antioxidant activities of Anabasis aphylla extracts. Kragujevac Journal of Science, 34, 71-78. 